\title{
Towards Energy Sustainability in South Africa
}

\author{
Ken Mathu \\ Vaal University of Technology
}

\section{Doi:10.5901/mjss.2014.v5n27p1686}

\begin{abstract}
Coal is one of the three fossil fuels which are the main source of energy in the world. The other fossil fuels are crude oil and natural gas. Coal exists in situ in a number of countries and it contributes $39 \%$ of the total electricity generation in the world. In South Africa coal is the primary source of energy producing the country's $88 \%$ of electricity and a third of liquid fuels. The coal production in the world is geared to maintain the energy supply even with the rising energy demand and cost emanating from rising global population and industrialisation. Hence, the need for sustainable energy supply for the present and the future. The global phenomenon of climate change or global warming which emerged in the early 1990 s blames the weather pattern change partly to human development using non-renewable energy (fossil fuels) that provide high carbon emissions into the atmosphere. As a result, United Nations Convention on Climate Change (UNCCC) was formed to lead the global campaign for the development of cleaner energy (producing less carbon emissions) and intensifying the use of renewable energy sources (produce cleaner energy) in an effort to slow down the climate change. During the last quarter of 2013 scientists reached a consensus by providing a 95\% proof that carbon emissions into the atmosphere contribute significantly to the climate change. Therefore, the pursuance of energy sustainability is in development of clean energy from renewable sources and the use of technologies that reduces carbon emissions from the existing sources. The United Nations require all the nations in the world to adapt to the energy sustainability initiative. The South African government has reciprocated by introducing legislations supporting the initiative and has provided funds in support of projects involved in energy saving and development of renewable sources of energy.
\end{abstract}

Keywords: energy-sustainability, fossil-fuels, renewable-energy, coal, climate-change.

\section{Introduction}

Coal is one of the leading sources of energy in the world. It is use a fodder in power stations for the generation of electricity and contributes $39 \%$ of the total global electricity production. It is also used as a catalyst in heavy industries and for cooking and space heating at homes. In South Africa, coal is the primary source of energy contributing $88 \%$ of the country's electricity generation and a third of the national liquid-fuels production.

The global coal producing countries strives to maintain the rising energy demand resulting from rising population and rapid industrialisation. The trend for ever rising energy demand requires a suitable supply model to satisfy the present and the future requirements.

The emergence of the climate change or global warming phenomenon from early 1990s was grounded on the believe that the unusual change in the global weather pattern was partly due to increased level of greenhouse gases in the atmosphere emanating from coal combustion in coal-fired power stations and industries. The extensive use of nonrenewable energy sources such as fossil under which coal falls was seen as a danger to the environment due to the high level of carbon emissions. Coal has the highest level of carbon emissions compared to the other fossil fuels crude oil and natural gas.

However, the unusual global weather pattern (climate change) led to the formation of the United Nations (UN) body 'United Nations Convention on Climate Change' (UNCCC) in early 1990s to mitigate the situation. A series of UN earth summits to establish the cause of climate change followed commencing with 'Argentina Earth Summit' in 1992. During the last quarter of 2013, climate scientists reached a 95\% consensus that greenhouse gases and in particular carbondioxide emissions actually contributes towards the climate change.

Therefore, the journey towards energy sustainability involves intensification of clean energy development from renewable sources and use of technologies that reduce carbon emissions from the existing sources. The main renewable sources of energy include hydro power, solar, wind, biofuel and geo-thermal. The nuclear power is not renewable, but it falls under this category because of its limited carbon emissions into the atmosphere.

Subsequently, sustainability has gained prominence as it is the holistic process of pursuing dependable clean 
energy for development and responsibility to the environment ensuring survival of organisms, clean water, soil and plant lives in it now and in future. All the nations which are members of the UN are required to have legislations and regulations supporting sustainability initiative. The government of South Africa has legislations and regulations in support of the sustainability initiative and has pledged funds in support of projects involved in energy saving and for development of renewable energy.

\section{Problem Statement}

The problem statement for the study was to establish the plans and processes being undertaken in South African towards achieving energy sustainability. The uses of non-renewable and renewable energy sources were explored and how they impact on the climate change.

\section{The Purpose of the Study}

The purpose of the study was to establish the progress in South Africa towards realisation of energy sustainability. This included looking at legislations, plans, projects and the government support for the energy sustainability initiative.

\section{Methodology}

The study adopted a qualitative research paradigm. According to Cooper and Schindler (2008: 162-168) the outcome of the qualitative interview depends very much on how the researcher prepares the participants for the interview. 'Qualitative research has substance, gives insight, shows sensitivity and is unique in conceptualisation, yet grounded in data' (Corbin \& Strauss 2008: 302).

Various aspects covered by this study included selection of participants, undertaking the interview, feedback on the interview for validity/reliability and facilitating data collection in a recorded form using an audio data recorder and field notes. Citing Goddard and Melville (2005: 49) the researcher must not direct the participant's answer through his tone of voice or rephrase the research question. Research design involves activities of 'collecting and analysing data, developing and modifying theory, elaborating or refocusing the research questions, identifying and addressing validity threat' (Maxwell 2005: 2).

The selection and profile of the participants was done using purposive sampling process. The process aimed to enhance understanding of the selected people and groups as they were selected for a specific purpose, task or expertise in research. 'The researcher should be in a position to expound the use of purposive sampling in order to instill confidence and validity for research findings' (Devers \& Frankel 2000: 264-265). The participants for this study were the top professionals who were also involved in decision making in their respective organisations in order to provide credibility to the study. There were 14 respondents earmarked for this research and 13 of them responded: 12 respondents were interviewed at their work place while 1 respondent provided a telephonic interview. The interview population of the 13 respondents comprised 4 Chief Executives and 9 senior professionals in the mining and affiliated industries nominated by their respective chief executives.

\subsection{Sample and Procedures}

The researcher is required to obtain permission from gate-keepers of the target institutions in order to obtain access to individuals and institutions (Ehigie \& Ehigie 2005: 622-623). The permission to conduct research either oral or written is paramount (Cooper \& Schindler 2008: 37). The objectives for the research were addressed at the initiation stage as the researcher approached the institutions' gate-keepers by stipulating the value proposition for the study, purpose and ethical considerations that also addressed the 'informed consent' (admissibility for research process).

Some of the critical requirements for a researcher are skills in negotiation and relationship building to be able to successfully access the prospective respondents. In this study, the researcher approached the selected participants via telephone and e-mail and briefed them on the value proposition for the project. Since the respondents were senior executives in their respective companies, some of them responded directly, while the others responded through their personal assistants. In two occasions the researcher was invited to give a presentation on the purpose of the research before the consent to interview was granted. A research introduction letter from the Vaal University of Technology formed part of the presentation. The content of the letter included the introduction of the researcher, confidentiality undertakings and the use of audio digital data recorder for recording the interviews. 


\subsection{Data Analysis}

The use of the audio digital data recorder and the field notes were the methods used for data collection. The collected data was transcribed and content analysis was used for the translation and analysis. The emerging themes and subthemes were recorded and evaluated to establish constraints that exist in the industry that would be resolved by the public-private partnership model.

\subsection{Reliability and Validity (Measures of Trustworthiness)}

Triangulation method was used to check the reliability and validity of data from this study. The process involved were comparing data from the interviews, feedback from the participants and from the literature. The researcher's field notes articulated the respondents' output. Some participants also provided written clarifications of some of their contributions after the interview. 'Multiple sources lead to a better understanding of the phenomena being studied' (Willis 2007: 219). Triangulation enhances validity and richness of data by looking at issues from different angles (Lee \& Lings 2008: 239).

\subsection{Ethical Procedures}

According to Eriksson and Kovalainen (2008: 68) research is vulnerable to 'lies, fraud and wrong-doing' hence, ethical adherence is paramount. The ethical issues for this study were addressed through the research introduction letter from the Vaal University of Technology addressed to those participants who had accepted the invitation for the interview. The letter provided confidentiality, anonymity and use of pseudonyms between the respondent and the researcher.

\section{Results}

Table 1: Themes and sub-themes emanating from the interviews

\begin{tabular}{|c|c|}
\hline THEMES & SUB-THEMES \\
\hline $\begin{array}{l}\text { Coal: origin, reserves, quality, business model, } \\
\text { production, consumption and trade (economic } \\
\text { benefits/welfare of employees and communities }\end{array}$ & $\begin{array}{ll}\text { - } & \text { Coal and its properties, reserves, production, } \\
& \text { consumption and trade } \\
\text { - } & \text { Employee satisfaction } \\
\text { - } & \text { Community welfare } \\
\text { - } & \text { Environmental impacts } \\
\end{array}$ \\
\hline Legislative environment (MPRDA, NEMA, NERSA) & $\begin{array}{ll}- & \text { MPRDA Act of } 2002 \\
- & \text { NEMA Act of } 1998 \\
- & \text { NERSA }\end{array}$ \\
\hline $\begin{array}{l}\text { Role players: coal mines (private), Transnet - rail } \\
\text { infrastructure (public) and South African Chamber of } \\
\text { Mines (private) }\end{array}$ & $\begin{array}{ll}\text { - } & \text { Coal mines } \\
\text { - } & \text { Transnet (rail transport) } \\
\text { - } & \text { South African Chamber of Mines (advisory role to the } \\
& \text { mining industry) }\end{array}$ \\
\hline $\begin{array}{l}\text { Environmental issues: pursuing green management } \\
\text { issues as per legislations, funders and social } \\
\text { responsibility. Committed to "cradle to grave" philosophy } \\
\text { of green environment }\end{array}$ & $\begin{array}{ll}\text { - } & \text { High carbon energy environment: carbon emissions, } \\
\text { dust, noise and diesel pollution }\end{array}$ \\
\hline
\end{tabular}

Source: Mathu (2011: 222-223)

Table 1 indicates the themes and sub-themes that emanated from the study. The themes focus on the history and properties of coal; legislative environment; coal supply chain role players and environmental impacts. Both the themes and sub-themes are discussed hereunder: 


\section{Discussion}

The four major themes that emerged from the interviews with the respondents indicated that South Africa has a predominantly coal-based energy focus. The fossil based non-renewable energy has far reaching impact on the national economy and the environment. The legislations are widely in favour of coal production for domestic and export markets. However, they also address the environmental protection through responsible mining practices. A detailed reflection of the coal use for energy production and the future plans were elaborated from the interviews. The respondents were professionals and decision makers from across the industry as elaborated herewith:

\subsection{Coal and lts Properties}

Africa holds $5.7 \%$ of the world coal reserves and $90 \%$ of the reserves are in Southern Africa. Coal is a fossil fuel and a primary source of energy in South Africa. It is formed from accumulation of dead vegetation over many years, undergoing a slow decaying process turning into peat that transforms into coal seams (Anglo Coal 2007: 47). According to Abbott, Apostolic, Goodman, Hortsman, Jenner, Jewell, Labhart, Maragos, May, Sunderman, Parke, Stein, Wengler and Went (2009: 53) the slow formation process that takes millions of years make coal a nonrenewable source of energy.

South African coal is associated with the Karoo rock formations which extend over the present day Free State, Mpumalanga, Limpopo and Western Natal. The chemical composition and properties of coal determine its usage. South African coal is less reactive, harder and has lower sulphur content compared to coal from the Northern hemisphere. The bulk of South African coal is bituminous or thermal grade suitable as fuel for electricity generation and anthracite suitable for metallurgical plants (Lang 1995: 20).

Carbon contents determine the calorific value (heat value) and it is used in the classification of coal (Abbott et al., 2009: 53) viz:

\subsubsection{Lignite Coal}

It is the lowest ranked coal with carbon content of $25-35 \%$ and it is mainly used in power stations to generate electricity.

\subsubsection{Sub-bituminous Coal}

It has higher calorific value than lignite, contains $35-45 \%$ carbon and its main use is also as fodder for the power stations.

\subsubsection{Bituminous Coal}

It has higher calorific value than sub-bituminous, contains $45-86 \%$ carbon and it is used for power generation and in the metallurgy industry as 'coke' for the production of iron and steel.

\subsubsection{Anthracite Coal}

It is the highest ranked coal in quality and it is hard, glossy and black. It possesses the highest calorific value, contains 86-97\% carbon and it is mainly used for residential and commercial space heating.

\subsubsection{Graphite Coal}

It possesses the same quality with anthracite and it is mainly used in pencil making and as a lubricant when powdered.

\subsection{South African Coal Reserves}

South Africa has coal reserves of approximately 30408 million tons, the sixth largest coal reserves in the world. The coal reserves are found in Mpumalanga, Free State, Limpopo, Kwa-Zulu Natal and Limpopo coalfields (DMR 2009:44).

The South African coalfields are mainly concentrated in the Mpumalanga coalfields where most of the coal-fired power plants are situated. The 650 kilometres rail line that transports coal to the Richards Bay Coal Terminal for export also runs from this area. Mpumalanga Province presently produces in excess of 70 percent of the South African coal, but the reserves are currently running low (depleting). It is estimated that from around 2020, coal mines in the Mpumalanga 
area will start relocating to the Waterberg coalfields in Limpopo Province which has abundant, untapped coal reserves (Chamber of Mines 2009:27).

There are 73 collieries in South Africa (Prevost 2009: 27). Most of them are owned by the five leading mining companies that produce over 80 percent of coal in the country and the others are owned by smaller black economic empowerment (BEE) mining companies or junior miners that contribute the remaining $20 \%$. The national distribution of the collieries comprises: Free State (2); Gauteng (1); Kwazulu-Natal (7), Limpopo (2) and Mpumalanga (61).

\subsection{South African coal mining business model}

There are two types of business models for coal mining in South Africa namely domestic and export models. The domestic model has three stages which comprises the mining process, transportation to the domestic customers/consumers and the processes at the customers' facilities who are usually the consumers. The export coal model also has three stages which are mining process, transportation to the coal export terminal by rail and shipping to overseas customers by sea. The export terminal is at Richards Bay along the Indian ocean coast of Kwa-Zulu Natal. The following figure shows the South African coal mining business model depicting both domestic and export markets.

Figure 1: The South African Coal Mining Business Model for domestic and export markets

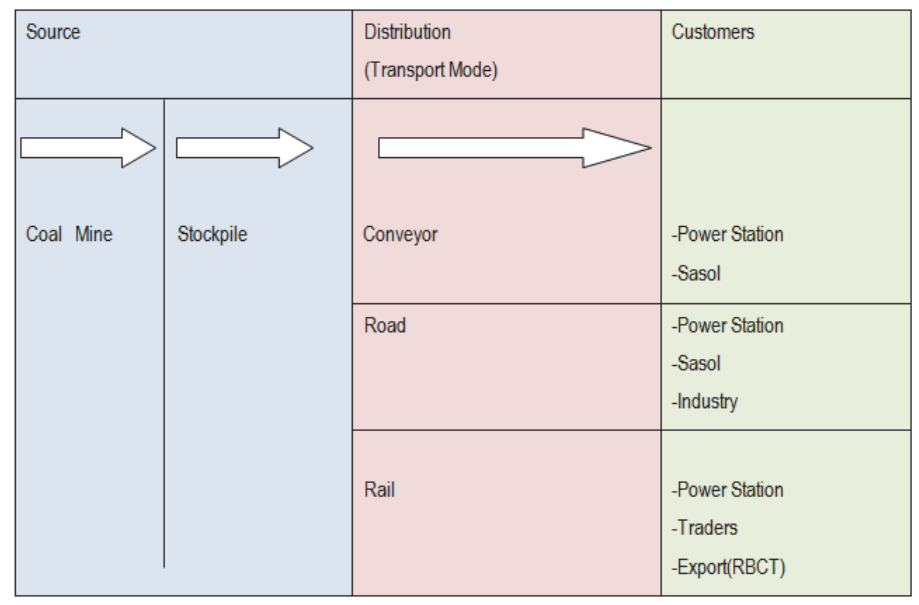

Source: Mathu (2011: 63)

The South African coal mining business model has three main stages: source (coal mining/ beneficiation), transportation (mode of transport used) and customers/ consumers.

\subsubsection{Stage 1: Mining}

The mining process involves removal of overburden on the top of the mine and coal that is brought to the surface mixed with rocks. The rocks are sorted from coal and delivered to a dump site. Coal free of rocks is stockpiled on a site allocated near the mine.

\subsubsection{Stage 2: Distribution (Transportation)}

Three types of transport modes are used for local distribution to the customers' conveyor, rail and road while rail and ship are used for export. The power station coal is delivered direct from the stockpiles and does not go through the beneficiation process. The bulk of the power station coal is delivered via conveyor belts. The rest is delivered by road and rail. The export coal is taken through the beneficiation process and delivered to the export terminal by rail. The coking coal for metallurgical industry, cement industry, aluminium smelters and for the traders is delivered by road and rail. 


\subsubsection{Stage 3: Customers}

The domestic customers for coal are the power stations, SASOL, industry and traders while the export customers abroad are the power stations and industry.

\section{Coal Production}

The South African coal mines are predominantly situated in the Mpumalanga coalfields. The future of South African coal mining is in Waterberg coalfields in the Limpopo Province after depletion of coal reserves in Mpumalanga deteriorates around 2020. Mining companies have already started identifying their relocation to Waterberg. The giant Medupi power station is located there and on completion it will be supplied by Exxaro mining company (Eskom 2011: 88)

A report from Eskom indicated that mining development has stalled in the last ten years. It also indicated a projection of up to 2018 comprising 43 new mines at an estimated cost of about R 100 billion and raising the 2008 national production estimate of $270 \mathrm{mtpa}$ to $370 \mathrm{mtpa}$ by 2018 . Those mines would be developed by the existing leading mining groups in the industry and just a few to be developed by the Black Economic Empowerment companies (Eskom 2009: 15).

South African coal production has stagnated since 2004 while consumption by Eskom has risen to meet the continued rising power demand. The scenario puts Eskom in competition with the other domestic consumers, resulting in price hikes and this has forced Eskom to use discarded coal from the big coal exporters in order to meet their requirements. The demand will continue to outstrip supply for some time until new coal mines come on stream (Smuts 2008:36). Presently, Eskom is building two giant coal-fired power stations Medupi and Kusile which will be completed in stages from 2014 (Eskom 2011: 88-89).

\section{Coal Consumption}

There are two categories of coal usage in South Africa namely domestic consumption and export markets. The domestic consumption is predominantly by Eskom power stations for the generation of electricity, Sasol for transformation into synthetic fuels and petrochemical products, steel and cement industries, aluminium smelters and homes for various applications.

\subsection{Coal for the Generation of Electricity (Eskom)}

Eskom is a South African government-owned power utility company that consumes the bulk of coal produced in the country as fuel for the generation of electricity through its current 13 coal-fired power plants which generate 88 per cent of the national electricity (Eskom 2009: 226). Eskom is one of the top 10 utilities in the world by generation capacity (Eskom 2009: iii). This is an indication of the size and capacity of the utility. The company's electricity generation mix comprises coal, hydro, pumped storage and some imports. This brings the total nominal capacity to 44193 megawatts (MW) (Eskom 2009: iii).

Eskom consumes approximately 50 percent of the coal produced in South Africa and approximately 66 percent of the total domestic coal consumption. Its consumption in 2011 was 124.7 million tons of coal (Eskom 2011: 11). The power crisis of 2007/2008 impacted heavily on the company and on the economy as well as communities. The coal stockpile at the power stations had deteriorated due to poor coal logistics, among other factors. As a result, Eskom was forced to step up coal transport by road to the detriment of the environment in the Mpumalanga area where most of the coal-fired stations are located (Bischoff 2009: 100).

This study established during the interviews that coal transportation is done 70 percent by conveyor belts, 24 percent by road and 6 percent by rail. The future plan is to reduce road transport to below 6 percent and increase rail transport to more than 24 percent. Eskom is under pressure to control costs and rail transport is viewed as being more economical, safer and sustainable (Eskom PE Division 2008: 12).

Eskom uses a network of national grid to transmit and distribute power directly or through municipalities. The national grid comprises 395 419km power lines (Eskom 2011: 169).

\subsection{Coal for Production of Liquid-Fuels and Petrochemical Products (Sasol)}

South African Synthetic Oils (Sasol) is a South African public company founded in 1950 and has international operations 
in a number of countries. The company manufactures a wide range of petrochemicals and synthetic fuels. It supplies a third of South Africa's liquid fuel requirements. It is also the country's single largest industrial investor, as well as the largest chemical feedstock producer. Its contribution to the Growth Domestic Product (GDP) is 4.7 percent amounting to R 40 billion a year (Sasol 2012: 11)).

'Sasol's primary business is based on coal-to-liquid (CTL) and gas-to-liquid (GTL) technologies using FischerTropsch synthesis. CTL and GTL plants convert coal and natural gas respectively into liquid fuels. The company has GTL projects countries such as Qatar, Nigeria and china. The Fischer-Tropsch synthesis has adverse effect in massive emission of carbon dioxide into the atmosphere. Indeed, the company's Secunda plant is one of the world's single largest emitter of carbon dioxide.' (Sasol 2008: 83).

\subsection{Coal Use in Industry and Home}

Coal is transformed under high temperature of approximately 1000 degrees Celsius into coke for use as a reducing agent fuel in the smelters in blast furnaces (Crawford 1993: 5). It is used for cooking and space heating in homes and industries (Chamber of mines 2009: 25).

\section{Coal Trade}

The South African coal trade covers both domestic and export markets. The domestic market is dominated by Eskom, Sasol, steel and cement industries, aluminium smelters and domestic market comprises 75 percent of total coal produced in the country. The remaining 25 percent is exported. Taking example of 2008, the distribution of the South African coal market estimated at 252.2 (Mt) was $194.3 \mathrm{Mt}$ for the domestic market and $57.9 \mathrm{Mt}$ for export. A further distribution ratios were as follows: power generation - Eskom (124.35mtpa), Sasol (44mtpa), industries (9mtpa), merchants (12.25mtpa) and exports (57.9mtpa) (Prevost 2008:7).

However, coal trade has stagnated in the last decade due to limited capacity of shipment from Mpumalanga coalfields by Transnet Freight Rail (TFR) for reasons such as inadequate wagons and other operational factors. According to Transnet 2013 Annual Report, TFR capacity reached 81mtpa and the projection is $97.5 \mathrm{mtpa}$ in 2020 (Transnet 2013: 140).

The local coal price per ton Free on Rail (FOR) averaged R 150.40 per ton in 2008, a 40.5 percent increase on the 2007 price. The average export price FOB (Free on Board) was R 704.62 per ton in 2008, a 94.5 increase over the 2007 price. The rise in local price was mainly attributed to higher mining costs resulting from higher input costs. Presently, the price of coal is USD 82.31 which is equivalent to ZAR823.10 at the exchange rate of R10 for 1USD (Coal Trader 2013: 1).

\section{Legislative Environment}

This study concentrated on the legislative environment from the South Africa's Department of Mineral Resources, Department of Energy, Department of Water and Environmental Affairs and the National Energy Regulator of South Africa.

\subsection{Department of Mineral Resources (DMR)}

The Department of Mineral Resources (DMR), previously Department of Minerals and Energy (DME), uses the Mineral and Petroleum Resources Development Act (MPRDA) - Act 2002 (Act No. 28 of 2002) that was promulgated in April 2004 in the administration of the mining industry (Government Gazette 2006: 3).

\subsection{Department of Energy (DoE)}

The DoE has legislations and regulations covering the energy sector. Among the legislations are renewable and alternative fuels (biofuels, hydro, solar, wind); nuclear (non-proliferation and safety); energy efficiency regulations and clean energy education (Government Gazette 2010: 10). 


\subsection{Department of Water and Environmental Affairs (DW\&EA)}

The Department of water and environmental affairs (DW \& EA) ensures that mines has environmental management plan (EMP) based on the principle of integrated environmental management as provided by the National Environmental Management Act (Act No. 107 of 1998) NEMA (Government Gazette 2010: 3)

\subsection{National Energy Regulator of South Africa (NERSA)}

The National Energy Regulator of South Africa (NERSA) is the precursor National Energy Regulator (NER) established in October 2005 to regulate the energy sectors in electricity, piped gas and petroleum. Established under Section 3 of the National Energy Regulator Act, 2004 (Act No. 4 of 2004), NERSA's mandate is to maintain a delicate balance between the regulated energy industries, users and consumers (NERSA 2008:16). The regulatory body advises the electricity and other energy institutions on the tariffs they charge the consumers and arbitrates grievances between the consumers and the energy distributors, among other roles. This ensures that the end users and consumers receive appropriate service and pay the correct rates recommended by the government (NERSA 2009:11-15).

The institution also provides electricity tariffs and has lately added the licensing of renewable energy projects and renewable energy feed-in tariffs (energy prices for independent power producers' to the national grid owned by Eskom).

\section{Transport}

The modes of transport in the South African coal industry supply chain are conveyor belts, rail, road and marine or water transport. The conveyor belt are used in in what is known as 'tied-colliery' contract between Eskom power stations and adjacent coal mines that were planned specifically to supply a designated power station. Most of the coal-fired power stations are located in Mpumalanga coalfields. Even the two new power stations Medupi and Kusile will be supplied under similar contracts. Medupi will be supplied by Exxaro and Kusile by Anglo American under a 40 years contract (ESKOM 2009: 65).

Since coal has started depleting at Mpumalanga coalfields, the power stations are supplied the top-up coal from other mines by road. As a result, the roads in Mpumalanga are badly damaged and the heavy coal-trucks have increased road accidents, air/noise pollution (environmental degradation).

The rail system is owned by state logistics company Transnet through Transnet Freight Rail (TFR) and it is predominantly used for export coal from Mpumalanga to Richards Bay Coal Terminal (RBCT). It is also used to transport coal to a few power stations. (Transnet 2009: 124)

The marine transport in the South African coal mining industry supply chain is only used for coal export from the main export terminal at RBCT and other harbours.

The port of Richards Bay is situated 170 kilometres north of Durban on the Indian ocean coastline. It was opened in 1976 and commenced with an export capacity of 10Mtpa. This capacity grew over the years and reached a capacity of 72Mtpa in 2008 (Goussard 2009:8). The capacity reached 76mtpa in 2009 (Prevost 2009: 7) and by 2010 its expansion reached 91mtpa. Richards Bay Coal Terminal (RBCT) is the largest single coal export terminal in the world, exporting more than 69 million tons annually (DMR 2009:47). In 2011 the port exported 65.5mt and 68.3mt in 2012 (Mining Weekly 2012: 1).

RBCT is connected to the coal mines via Transnet Freight rail (TFR) running from Mpumalanga coalfields to Richards Bay terminal along the Indian ocean. The terminal coordinates with the Transnet National Ports Authority (TNPA) for the arrival and departure of more than 700 ships per annum (Coal International 2007: 12).

\section{Chamber of Mines of South Africa}

The Chamber of Mines of South Africa is a voluntary membership private organisation which was founded in 1889 to look into the affairs of the mining industry. The Chamber liaises with universities and international organisations for mining related research and bridges between the government, labour unions and the mining industry (Chamber of Mines 2009: i).

\section{Environmental Impacts (Constraints)}

All the participants reaffirmed a continuous liability in managing 'green' issues as required by the mining legislation and 
the willingness of their respective organisations to respond to the requirements. The legislation would ensure control of the dilapidated ownerless coal mines, continuous burning of coal mine dumps, air and water pollution.

The power generation from coal consumes approximately $50 \%$ of the total coal mined in South Africa and the production of synthetic liquid-fuels and petrochemicals consumes 18\%. These energy producing processes are the leading carbon emitters in the country and hope to employ more effective measures in future to control the emissions (Lloyd 2002: 47).

It is estimated that by 2020 South Africa will increase coal production by $75 \mathrm{mtpa}$ and production of clean energy from renewable sources and nuclear would increase tremendously according to the 2010 Department of Energy's integrate resource planning (IRP2). The country has a target of reducing of reducing carbon emissions by $34 \%$ from a business-as-usual scenario in 2020 and 42\% in 2025 (Salgado 2010b: 19).

According to a phenomenon called' Lloyd's Blanket Atmospheric Pollution', a European satellite image above Mpumalanga and Gauteng Provinces indicate a high level of nitrogen dioxide atmospheric pollution due to coal-based electricity generation in the region (Abbott et al. 2009: 87). The future energy generation and consumption from coal sources will require technologies which would control carbon emissions and sustainable modes of transport on land (Resource 2010: 16).

Presently, more than three-quarters of South African carbon emissions come from energy generation and consumption. Therefore, increased energy mix will reduce coal use drastically in order to realise the anticipated target for 2020 and 2025. 'The current coal-fired power stations will be decommissioned by 2025 when their economic life expires. However, the new coal-fired-power stations that will come on stream in future including the two new ones under construction Medupi and Kusile, will use clean coal technology (CCT)' Eskom 2009: 59).

The respondents concurred that the environmental degradation by excessive use of transportation of coal by road would be controlled by building additional rail lines linking the coal mines with the power stations in future. The extensive use of rail transport would also reduce noise and air pollution.

The philosophies of 'cradle to cradle' and 'cradle to grave' according to the respondents, means that companies should manage their products' life cycle in both forward (towards point of sale) and backward (reverse logistics) movements in the supply chain.

\section{The Future of Coal Mining in South Africa}

The future of South African coal mining lies in coalfields which were identified in the past, but were never exploited due to constraints such as the lack of infrastructure, difficult coal mining conditions, high ash content and low calorific value (CV). 'These massive areas include Waterberg, Springbok Flats, Limpopo, Soutpansberg, Tuli, Mabopane, Venda-Pafuri and the Free State coalfields. They contain younger coal compared to that of Mpumalanga coalfields. The Waterberg coalfields alone contain about 3.4 billion tons of coal or 11 percent of South African recoverable coal.' (Prevost 2008: 6-9)

The South African coal mining sector has medium and long-term plans to increase coal production capacity. 'Presently, the industry has R15.5 billion worth of projects underway which could yield about $36 \mathrm{Mt}$ of extra coal production, while also sustaining production at some mines. Another $63 \mathrm{Mt}$ worth approximately R 30 billion is in the final feasibility stage. It is estimated that about R100 billion will be invested in the industry over the next decade if targets are to be achieved.' (Chamber of Mines 2009:27).

With the Mpumalanga coalfields being presently overexploited, the future of South African coal production lies in the Waterberg coal fields in the Limpopo Province (Prevost 2010:17). Eskom plans to construct new power stations in the area in future, commencing with the R110 billion Medupi dry-cooled coal power station which is under construction outside Lephalale. The feedstock for the giant power plant of nearly 14.6 million tons of coal per year will be supplied by the Grootegeluk coal mine owned by Exxaro Resources. Another dry-cooled new coal power station with the same capacity Kusile is also under construction near the area and it will be supplied coal by Anglo Coal on completion. Each of the two power stations will have generation capacity of 4500 MW (Eskom 2011: 89-90).

The availability of water is a significant factor in the coal-mining industry. Large volume of water is required for mining, beneficiation and processing purposes (Prevost 2008:11). 'In the case of the Waterberg coalfield, the availability of water is a major inhibiting factor. 'The Matimba power station uses water from Makola Dam outside Lephalale. Presently, more water could become available by raising the level of Makola Dam, but it would not be enough for the earmarked development in the area. A geo-hydrology study is also being carried out to establish the availability of water in the area.' (Van Vuuren 2009:15). 


\section{Development Towards Energy Sustainability in South Africa}

Since the UN sponsored Kyoto Protocol Treaty of 1997 which actually became effective from 2005, South Africa has taken big strides towards energy sustainability. The country being among the leading 20 carbon emitters is moving in the right direction in trying to balance the predominantly carbon-based economy. The country supports the UN Convention on Climate Change (UNCCC) and has membership to the Conference of the Party (COP) and hosted (COP 17) in Durban in 2012. The South African government National Development Plan NDP 2030 has energy sustainability as among the top priorities. The NDP 2030 states, "The country will produce enough energy to support industry at competitive prices, ensuring access for poor households, while reducing carbon emissions per unit of power by about one-third".

The following are some of the highlights towards energy sustainability:

- Introduction of energy efficiency incentive in form of tax reduction for businesses that can prove verified energy savings as a result of implementing efficiency enhancements (Engineering News 2013: 1)

- Formation of Renewable Energy Independent Power Producers Procurement Programmes (REIPPPP) with support from the government and leading local commercial banks and development banks (Engineering News 2013: 1)

- World Wide Fund for nature (WWF) Climate Solvers initiative proposed to promote businesses addressing climate change. The companies that contribute to the transition to a low carbon economy through sustainable clean technologies, addressing wasteful consumption, poverty, creating jobs and increasing access to energy and reducing emissions

- Vehicle emission tax to be effected after a review in 2014

- Construction of green buildings

- New coal-fired power stations coming on stream such Medupi and Kusile designed on clean technologies

- Eskom initiative in development of solar power

- Wind farm power projects (Example: R1.2 billion Port Elizabeth project)

- Gauteng Province to roll out R11 billion solar panel project on roof tops of government buildings covering approximately 8 million square metres to generate 300 MW of electricity (Engineering News: 1 )

- Municipalities growing biogas industry by using waste water treatment (Example: Johannesburg Northern Waste Water Treatment Works producing 1.2 MW of electricity)

- Suggested initiative for development banks to fund developing countries producing coal to use it in the cleanest way possible expressed by the chairman of the World Coal Association at (COP 19) Summit at Warsaw, Poland in 2013 (Mining Weekly 2013: 1)

\section{Limitation of the Study}

The study being qualitative had a limitation on the number of participants. A total of 13 professionals from the coal mining industry and the role players were interviewed. Recruiting such high caliber professionals was time-consuming in accessing them and their institutions as explained in the methodology chapter. However, the response by the respondents from the industry was positive (13 approvals out of 14 proposals).

Accessing the industry had other limitations due to its nature as energy industry and energy is a sensitive subject because of its critical role in sustainable development. The institutions in the industry are not easily accessible without convincing reasons and introducing a research topic is not one of the most desired reasons to gain access. However, with skills and patience, it was possible to gain access and to successfully accomplish the project.

\section{Conclusion}

South Africa as a dominant coal economy is the second largest economy after Nigeria in the African continent. The country's medium and long-term plans as indicated by the NDP 2030 for the production of sustainable cleaner energy will enable it maintain the dominant economic position in the continent for a long time. However, fossil fuels will remain dominant in the Africa's energy mix. Improved energy efficiency improves cost and emissions when appropriate mitigating measures are applied. The only challenge with the renewable energy is its intermittence nature which renders it useless for base load supply, but coal will continue to play the role for base load supply.

Africa has a future potential in clean energy supply from the Inga dam on River Congo in the Democratic Republic of Congo. South Africa is part of the consortium planning the exploitation of River Congo hydroelectricity project and this 
will enhance clean sustainable energy for the country. The full potential of the Inga dam is $100000 \mathrm{MW}$ of electricity which would support most of the Sub-Sahara African countries and beyond.

\section{Recommendations}

The study recommends the introduction of intensive training programme on sustainability at all levels of the society starting with the industry, educational institutions and the communities. The purpose of the exercise would be to increase awareness to the population about the ecosystem and other activities including industrial taking place in their environment. Children should understand nature and life from very early age so that they become more conversant with sustainability issues as they move on to higher grades.

The social responsibility for companies should include sustainability education to their employees and the other stakeholders that include the communities around where they operate. The company reporting should take the model of global reporting initiative (GRI), but have it simplified so that more companies would provide their sustainability reports. It is only by taking such initiative that nations would be able to make positive contributions towards greening the planet earth by making it sustainable and a better place for the present and future generations.

\section{References}

Abbott, K., Apostolik, R., Goodman, G., Jenner, M., Labhart, G., Maragos, S., MAY, M., Sunderman, A. D., Parke, J., STEIN, J., WENGLER, J. \& WENT, P. 2009. Foundation of Energy Risk Management: An overview of the energy sector and its physical and financial markets. Global Association of Risk Professional (GARP). Hobken, NJ: John Wiley.

Anglo Coal. 2007. Annual Report.

Bischoff, F. 2009. Coal haulage. IMIESA, October, pp.100-101.

Chamber Of Mines Of South Africa. 2009. Annual Report.

Coal International. 2007. International energy outlook. [Online]. Available at: www.eia.doe.gov/oiaf/ieo/coal.html. Accessed: October, 2008.

Cooper, D. R. \& Schindler, P. S. 2008. 10th ed. Business Research Methods. New York: McGraw-Hill.

Corbin, J. \& Strauss, A. 2008. $3^{\text {rd }}$ ed. Basics of Qualitative Research. Thousand Oaks (CA): Sage.

Crawford, O. 1993. Surface molecular anchoring in microfined liquid crystals near the nematic-smectic-A transition. [Online]. Available at: http://link.aps.org/doi/10.1103/PhysRevE.48.1998. Accessed. 23 April 2009.

Denvers, K.J. \& FRANKEL, M. 2000. The study design in qualitative research-2: Sampling and Data Collection Strategies. Education for Health, Vol. 13, No. 2, pp. 263-271.

Ehigie, B. O. Ehigie, R. I. 2005. Applying qualitative methods in organisations: A note for industrial/organizational psychologists. The Qualitative Report Volume 10 Number 3 September, pp. 621-638. [Online.] Available at: http://www.nova.edu/ssss/QR/QR103/ehigie.pdf. Accessed: 13 September 2010.

Engineering News. 2013(a). [Online]. Gauteng government rolls out ZAR11 billion solar panels project. Available at: http://www.engineeringnews.co.za/article/gauteng-to-roll-out-r11b-solar-panel-project-201...Accessed: 9 April 2013.

Engineering News. 2013(b). [Online]. South Africa weighs at appointments of more IPPs as green-energy portfolio expands to ZAR150 billion. Available at: http://www.engineeringnews.co.za/article/sa-weighs-appointment-of-more-ipps-as-green-e... Accessed: 5 November 2013.

Engineering News. 2013(c). [Online].Government introduces tax incentives to businesses to improve energy efficiency. Available at: http://www.engineeringnews.co.za/article/govt-introduces-tax-incentive-for-businesses-that...Accessed: 12 December 2013.

Eriksson, P. \& Kovalainen, A. 2008. Qualitative Methods in Business Research. London: Sage.

Eskom, Primary Energy Division. 2008. Annual Report.

Eskom. 2009. Annual Report.

Eskom. 2011. Annual Report.

Goddard, W. \& Melville, S. 2005. 2nd ed. Research Methodology (An Introduction). Durban: Juta.

Kovalainen, A. 2008. Qualitative Methods in Business Research. London: Sage.

Lang, J. 1995. Coal Mining in the Life of South Africa. Cape Town: Jonathan Ball.

Lee, N. \& LINGS, I. 2008. Doing Business Research: A Guide to Theory and Practice. London: Sage.

Lloyd, P. J. 2002. Coal Mining and Environment. Energy Research Institute, University of Cape Town.

Mathu, K. M. 2011. Supply Chain Constraints in South African Coal Mining Industry. Berlin: Lap Lambert.

Mining Weekly. 2012. [Online]. Available at: www.miningweekly.com Accessed: 10 January 2012.

Mining Weekly. 2013. [Online] Available at: http://www.miningwekly.com/article/gomwe-pleads-with-banks-to-back-coal-in-fight-a........ Accessed: 19 November 2013.

Maxwell, J. A. 2005. 2nd.ed. Qualitative Research Design: A alternative Approach. Thousand Oaks (CA): Sage.

National Energy Regulator Of South Africa (NERSA). 2008. Annual Report.

National Energy Regulator Of South Africa (NERSA). 2009. Annual Report. 
Prevost, X. 2008. Coal mining in South Africa. Inside Mining, pp. 6-9.

Prevost, X. 2009. Undergroung gasification. Inside Mining, September, pp. 7-9

Prevost, X. 2010. A clean future for coal. Inside Mining, April/May, pp. 14-17.

Republic Of South Africa (RSA). Department of Environmental Affairs and Tourism 2006. Environmental Management Plan (EMP). Government Gazette No. 28753. Vol. 490. Pretoria: Government Printer.

Republic Of South Africa (RSA). Department of Minerals and Energy. 2007/2008. South Africa's Mineral Industry (SAMI). Pretoria: Government Printers.

Republic Of South Africa (RSA). Department of Mineral Resources. 2009. Molato (Bana le Basadi ba tlile go tlo rera Molato). Johannesburg: Primedia.

Republic Of South Africa (RSA). Department of Mineral Resources. 2010. Mining Licenses Moratorium No. 33511, Vol. 542, Pretoria, 31 August.

Reublic Of South Africa (RSA). Department of Transport. 2006. Interventions to reduce freight and passenger transport costs. Pretoria: Government Printer.

Resource. 2010. Energy usage and climate change. May, pp. 16/18.

Salgado, I. 2009. South Africa's climate shift policy rates high. The Star, Business Report, July, p 5.

Sasol. 2008. Sustainable Development Result.

Sasol 2012 Annual Report

Transnet. 2009. Annual Report.

Transnet. 2013. Annual Report

Van Vuuren, L. 2009. Coal Mining's Impact on Waterberg Under Microscope. The Waterwheel Journal, March/April, p. 14.

Willis, J. W. 2007. Foundations of Qualitative Research (Interpretive and Critical Approach). London: Sage. 